\title{
Neither consenting nor protesting: an ethical analysis of a man with autism
}

Kate Diesfeld University of Kent, Canterbury, Kent

\begin{abstract}
This article critically examines the 25 fune 1998 decision by the House of Lords regarding the psychiatric admission of a man with autism. ${ }^{1} \mathrm{Mr} \mathrm{L}$ was able neither to consent to, nor refuse, that admission and the disposition of his case illuminates the current debate regarding best interests of vulnerable adults by the judiciary and the psychiatric profession. This article begins with the assumption that hospitalisation was not the optimum response to $M r L$ 's condition, provides alternative approaches to the interpretation of best interest and examines principles of liberty, anti-discrimination, and equal protection. (Fournal of Medical Ethics 2000;26:277-281)
\end{abstract}

Keywords: Informal admission; autism; discrimination

Facts

At the time of Mr L's admission, he was forty eight years old. He had autism and was unable to speak. His level of understanding was severely impaired, his complex needs required 24-hour supervision and he did not leave his home alone. He sometimes injured himself, had no concept of danger, and did not have the ability to consent to or refuse treatment. After residing at Bournewood Hospital for over thirty years, Mr L went to live with the Enderby family, his foster carers. Mrs Enderby described $\mathrm{Mr}$ L's intermittent behaviours as "tantrums", which occurred on average every four days, and never necessitated notifying the police because the Enderby family coped with these occurrences. On 22 July 1997, Mr L became agitated, banged his head against the wall and hit himself with his fists at the day centre he routinely attended. A local general practitioner administered a sedative and a social worker arranged transport to the accident and emergency room of the Bournewood Hospital where a psychiatrist determined that $\mathrm{Mr} \mathrm{L}$ required admission, based on those behaviours. The psychiatrist did not detain $\mathrm{Mr} \mathrm{L}$ as a formal patient under a section of the Mental Health Act 1983 because Mr L did not resist admission and was compliant. The psychiatrist reported that had $\mathrm{Mr} \mathrm{L}$ attempted to leave, $\mathrm{Mr}$ $\mathrm{L}$ would have been compulsorily admitted as a formal patient under the act. ${ }^{3}$ L:

Fennell ${ }^{4}$ has scrutinised the de facto status of $\mathrm{Mr}$

"In theory, as an informal patient, he could have walked out, but how meaningful is it to say that $\mathrm{Mr}$ $\mathrm{L}$, as a vulnerable and incapacitated patient, could have discharged himself, especially when his doctor intended to detain him if he did so?"

The judiciary's justification for this de facto detention warrants greater scrutiny.

\section{Benefits and disadvantages of formal admission}

There are four significant advantages of being a formal patient under the Mental Health Act 1983. A formal patient has access to the Mental Health Review Tribunal, which reviews the criteria for discharge, and access to the Mental Health Act Commission, which investigates complaints by, and on behalf of, formal patients. Unlike informal patients, section 3 formal patients are entitled to a second opinion for certain treatment for a mental disorder without consent pursuant to section 58. Also, section 3 formal patients, when discharged, are entitled to after care services pursuant to section 117.

There are obvious disadvantages to being formally detained, such as the stigma attached to involuntary detention and section 3 formal patients may be given medication for three months in the absence of their consent pursuant to section 63 . However, formal patients under section 3 are afforded those legal protections described above which ensure that they obtain independent supervision and review.

\section{The judicial decisions}

The issue was whether this admission was lawful based on whether the common law doctrine of necessity allows doctors to admit incompetent but compliant patients under section 131(1) of the act. ${ }^{5}$ The Court of Appeal found that Mr L's admission was unlawful because section 131(1) only applies to individuals who are admitted voluntarily and consent to treatment. ${ }^{6} \mathrm{Mr} \mathrm{L}$ was unable to consent to admission and therefore the court found that he had been unlawfully detained and his admission was a detention. Upon appeal, the majority of the House of Lords (Lords Goff, Lloyd and Hope agreed) held that such treatment did not amount to detention which constituted imprisonment for the purposes of the tort of false imprisonment. ${ }^{7}$ The minority (Lords Steyn and Nolan) agreed with the Court of Appeal that there was a detention which amounted to imprisonment but found that the detention was justified. ${ }^{8}$ 


\section{Best interests}

This portion of the article examines the rationale of the House of Lords through the lens of Mr L's best interest. Arguably, there is an ethical justification for state intervention to prevent self harm because such intervention may improve the quality of life and reduce the frequency and severity of the injuries, thereby perhaps allowing more freedom from restraint in its various forms for people with self-injurious behaviour. According to Schopp:

"Any plausible legal system must allow constraints on individual liberty in order to prevent harm to others or harm to self by clearly incompetent individuals... . In order to determine the appropriate scope and justified constraints on liberty, one must appeal to the broader political morality underlying the legal system...." ."

Examination of this political morality is essential when we investigate whether alternatives to hospitalisation are preferable for people with severe autism and challenging behaviours.

\section{A. Resource allocation}

Is the House of Lords' decision, which was based on allocation of resources, sufficiently concerned with Mr L's interests? Although "necessity" was cited in the Lords' decision, ${ }^{10}$ it was neither the first nor the dominant justification for the Lords' decision. The primary consideration was not based on the liberty, equality, or best interests of $\mathrm{Mr} \mathrm{L}$. The Lords' decision was explicitly premised on the fiscal impact of extending legal rights to $\mathrm{Mr} \mathrm{L}$ and other individuals with similar conditions:

"First and foremost, the effect of the (Court of Appeal's) judgment is that large numbers of mental patients who would formerly not have to be compulsorily detained under the act of 1983 will now have to be so detained. Enquiries by the Mental Health Act Commission suggest that 'there will be an additional 22,000 detained patients resident on any one day as a consequence of the Court of Appeal judgment plus an additional 48,000 admissions per year under the act'.... It is obvious that there would in the result be a substantial impact on available resources...."11

Although distribution of resources raises complex ethical dilemmas, the Lords' decision did not explicitly elaborate on the distributive justice implications. It could be argued that there is a utilitarian justification for not expending limited resources on people with autism if their interests could be met as informal, therefore less costly, patients. However, this implies that funding for the legal protection of those with conditions similar to $\mathrm{Mr} \mathrm{L}$ is better spent elsewhere, on more deserving people. Although the House of Lords' decision explained that deeming $\mathrm{Mr} \mathrm{L}$ to have been unlawfully detained would have led to the costly detention of $\mathrm{Mr} \mathrm{L}$ and thousands of others, it does not explain why those funds cannot, or need not, be channelled to informal patients.
The best interest and the fiscal impact approaches rest uneasily together. On the one hand, affording $\mathrm{Mr} \mathrm{L}$ and others the protections of a formal patient would be costly, thereby reducing funds in an apparently underfunded mental health and legal system. But refusing to extend the protections available to formal patients is difficult to justify on the basis of Mr L's best interests.

Arguably, the Lords' decision demonstrated an attempt to administer distributive justice. The appropriateness of that judicial prerogative is beyond the scope of this article. However, we must scrutinise the ethics of the Lords' decision which perpetuated the informal status of vulnerable and compliant patients on the basis of their best interests, when there was an explicit emphasis on the implications of limited financial resources.

\section{B. Alternatives to hospitalisation}

Did the House of Lords adequately investigate whether alternative provisions, rather than prolonged hospitalisation, would have enabled Mr L to flourish? Mr L's best interest may be conceptualised as that environment where he is most likely to flourish. Arguably, the hospital environment is not optimum accommodation for $\mathrm{Mr} \mathrm{L}$. There is by no means universal agreement that hospitalisation, with the consequent restriction on the lives of psychiatric patients, is therapeutic. Evidence suggests that specialised treatment services for challenging behaviours may be problematic. According to Emerson et $a l^{12}$ :

"These(problems) include the deleterious effects of congregating together individuals with severe problem behaviour upon user quality of life, staff stress and resulting turnover and difficulties with the person returning to his/her original setting, a move which is itself extremely difficult to arrange and is often associated with reduced level of programme implementation, increased use of mechanical restraint and failures to sustain treatment gains."

Other factors of hospitalisation make it less attractive than the community alternative. For example, the ratio of staff to patients in hospital may provide less individualised attention than in the community, thereby reducing the benefits of hospitalisation. Murphy ${ }^{13}$ reports:

"High staff engagement levels and skill development are almost never possible in a hospital setting for people with learning disabilities, so that it has to be concluded that institutions are unlikely to reduce challenging behaviours because of increased adaptive behaviours. On the other hand, challenging behaviours may decline in community settings as adaptive behaviours and engagement levels increase."

People with challenging behaviours are known to be at a high risk of readmission to hospital and they are also the last to be discharged ${ }^{15}$ which is not an optimistic prospect.

Mr L's best interests may have been better served by investigating his challenging behaviours in situ, 
thereby attempting to interpret the behaviours where they occurred. Ecological factors may be important in understanding challenging behaviours. Therefore, it may be helpful to view Mr L's behaviours as communicative ${ }^{15}$ and to develop more appropriate ways of communicating as a way of reducing the challenging behaviours. ${ }^{16}$

If $\mathrm{Mr}$ L's therapeutic interests were paramount, why was he hospitalised for twenty-one weeks without staff arranging visitation by the Enderbys? Also, after the initial incident at the day centre, there is no evidence of other incidents cited in either judicial decision which justify a lengthy hospitalisation following an incident which was characteristic of behaviour which the Enderby family historically managed.

In summary, the House of Lords decided that hospitalisation was merited for $\mathrm{Mr} \mathrm{L}$ on the basis of his self-injurious behaviour. However, research indicates that people with similar disabilities may benefit more by remaining in the community with observation and intervention, rather than in a restrictive environment.

\section{Legal best interests}

Should the House of Lords' decision incorporate an analysis of $\mathrm{Mr}$ L's legal best interests in their assessment of his wellbeing?

According to Schopp ${ }^{17}$ :

"Theorists ... can accept intervention contrary to incompetent choices when doing so is necessary to promote wellbeing, but they may differ regarding which aspect of wellbeing to emphasise."

It is crucial to acknowledge that there are a variety of interests which may contribute to Mr L's wellbbeing, including his legal interest in securing his liberty. The Lords emphasised Mr L's self-injurious behaviour, and held that it was in his interests to have clinical intervention as an informal patient but a broader interpretation would include his interest in having his legal interests protected.

Perhaps the Lords' options were limited; the scope of their decision making powers was confined to the decision whether the doctor could intervene on the basis of the necessity to reduce Mr L's selfinjurious behaviour. Perhaps the Lords were judicially unable to suggest alternative interpretations of best interest. However, if the judiciary is purporting to espouse a benevolent approach, it might arrive at another conclusion, namely that admitting a non-verbal person with autism to a psychiatric ward without legal protection, review, or entitlement to after care is not the best option.

We should grant priority to Mr L's legal protection, as one of a cluster of essential factors which should be weighed when defining his interests. Arguably, there is no need to extend the protections of formal status to $\mathrm{Mr} \mathrm{L}$ because they are non-essential and intervention may be provided to him with, or without, such legal safeguards. Also, in light of limited resources as discussed above, there may be minimal justification for extending costly legal protections when we are unlikely ever to "know" Mr L's thoughts, and when we are unlikely to discern whether he himself appreciates these legal safeguards. However, principles of liberty, equality, and anti-discrimination promote legal protection for the most vulnerable members of society.

\section{Liberty}

Were Mr L's liberty interests inadequately asserted by the House of Lords? Lord Goff of Chieveley stated that Mr L's admission "in so far as (the steps taken) might otherwise have constituted a violation of his civil rights, were justified on the basis of the common law of necessity." "18 This disregard for the essential liberty interests of $\mathrm{Mr} \mathrm{L}$ communicates boldly, and baldly, that the liberty interests of vulnerable individuals have not been strenuously supported by those who determined Mr L's claim.

In support of its position, the House of Lords cited the recommendations from the The Percy Commission Report 1957. ${ }^{19}$ Paragraph 291 recommended abandonment of the practice whereby "compulsory powers must be used unless the patient can express a positive desire for treatment, and replacing this by the offer of care without deprivation of liberty, to all who need it and are not unwilling to receive it". ${ }^{20}$ Further, "all hospitals ... should be free to admit patients for any length of time without legal formality and without power to detain." ${ }^{20}$

This approach disregards the intrinsic liberty interests of compliant people. Mr L and thousands of people with similar disabilities are admitted to psychiatric facilities where they are de facto detained. They have not given consent; rather, they have been admitted with the complete absence of consent. Mr L was thereby multiply disadvantaged: he was unable to leave because he was he was incapable of asking to leave; he was deprived of the protections associated with free legal representation before the tribunal, and he was unable to obtain independent scrutiny by the commission.

In keeping with the progress in conceptions of human liberty, Lord Steyn, ${ }^{21}$ in the minority, asserted the following:

"If considerations of financial resources are put to one side, there can be no justification for not giving to compliant incapacitated patients the same quality and degree of protection as is given to patients admitted under the Act of 1983."

Obviously, the House of Lords was grappling with the complex issue of how society should respond to the severely challenging behaviours of some people with autism. But this issue depends on the more fundamental question of what value our society places upon legal safeguards for our most disabled members. By locating Mr L on a par with people who actively consent to admission, the House of Lords ignored Mr L's unique charateristics, that mental disability which rendered him unable to articulate his own interests. 


\section{Discrimination}

Current anti-discrimination initiatives assert that all people must be treated equally under the law. The Disability Discrimination Act 1995 (DDA) explicitly promotes the equality of persons with disabilities in Britain and states that people with mental disabilities must be protected from less favourable treatment. Although this legislation was not the subject of the cause of action, it could be argued that the House of Lords contravened its spirit by deciding as they did. Moreover, it is contended that the DDA should apply to situations such as this one.

Admittedly, treatment and detention are not explicitly included in the provisions of the DDA nor was part III, which governs services, implemented by June 1998. Nevertheless the DDA is intended to eliminate discrimination in many forms far less fundamental to human liberty than psychiatric detention. The House of Lords had the opportunity to invoke the anti-discrimination principles on behalf of those individuals who, as yet, have infrequently utilised even the employment and education provisions. Application of the principles of the DDA is warranted because those more disabled individuals, such as Mr L, who may never be employed or access advanced education, are routinely subject to gross forms of discrimination.

\section{Fundamental advance}

The legislation is intended to integrate people with disabilities who historically have been politically, economically, and socially disadvantaged. The Minister for Disabled People asserted that the DDA is a "fundamental advance, a foundation upon which we can build to achieve the end of discrimination". ${ }^{22}$ Surely the discrimination which Mr L experienced by being deprived of legal protections, and the severity of Mr L's disability, are precisely the type of discrimination and the type of disability which are to be governed by the legislation. All people with qualifying disabilities must be covered, not merely people who are verbal, less disabled, less costly, and more economically productive.

Whether the DDA applies would depend on whether hospitalisation qualifies as a service, whether Mr L was treated less favourably for a reason related to his disability, and whether a justification for that treatment applies. Part III of the DDA prohibits discrimination against people with disabilities in the provisions of services; public authorities are governed by the act and in parliamentary debates it was "clear that legal and health services would be covered". ${ }^{23}$ Thus, it could be argued that $\mathrm{Mr} \mathrm{L}$ would be protected under the act if the informal admission was discriminatory. A service provider discriminates if he or she treats the disabled person less favourably for a reason which relates to the person's disability and it cannot be justified under the act, pursuant to section 20(1). We must ask whether Mr L was treated less favourably than a non-disabled person. It could be asserted that $\mathrm{Mr} \mathrm{L}$ was treated less favourably than other patients who are actively refusing to consent, but are afforded legal protections as formal patients.

Mr L might have to overcome the assertion that the DDA does allow treatment which would be otherwise discriminatory pursuant to section 20 (3) and (4) if that provider could justify the treatment. One such justification is when "the treatment is necessary in order to not endanger the health and safety of any person (including the disabled person)". ${ }^{24}$ It could be argued that $\mathrm{Mr} \mathrm{L}$ was admitted informally to prevent his self injury, and therefore the informal admission was justified on the basis of his health and safety. Conversely, it could be asserted that Mr L would be equally protected, with added legal safeguards, if he were afforded the same treatment as formal patients under the DDA.

Also, Mr L's case demonstrates a complex form of discrimination which requires an ethical analysis of discrimination between people with mental disabilities, which may be conceptualised as an equal protection analysis.

\section{Equal protection}

Historically the concept of equality has been employed as a powerful ethical and legal instrument and is particularly pertinent in Mr L's case. Almost all modern constitutions include equal protection clauses directed against arbitrary discrimination and aiming to ensure equal rights. ${ }^{25}$ Two propositions are included in this conception of equality: equality before the law and equal protection of the laws. Accordingly, citizens all enjoy equal access to society's legal tribunals and other dispute resolution, and all are entitled to impartiality in administration of justice. ${ }^{26}$ These principles stress that there must be independent tribunals to which all may resort. "Equality before the law is often said to be one of the fundamental characteristics of the British constitution." ${ }^{27}$ Also, according to Lord Scarman, every person within the jurisdiction is entitled to the equal protection of the law. ${ }^{28}$ Despite the fundamental importance of this principle, it was not an element of the House of Lords' decision.

This failure to employ an equal protection analysis may in itself be symptomatic of the judiciary's failure to acknowledge Mr L's unique legal status. An ethical outcome "demands that laws will only be legitimate if they can be described as just and equal". ${ }^{29}$ Arguably, an equal protection approach is not appropriate because Mr L's condition renders him different from an objecting psychiatric patient who is detained under the act. If Mr L's compliance can most conveniently, and resourcefully, be construed as equivalent to consent, perhaps $\mathrm{Mr} \mathrm{L}$ should only be afforded the protections of an informal patient.

However, an equal protection approach may assert that even between classes, at least some differentiation and certain kinds of discrimination should be avoided. ${ }^{30}$ In the case of people with 
autism, this would mean that protections must be established which afford them the greatest protection, equivalent to objecting formal patients.

Principles of equal protection are included in the famous declarations on human rights of the United States, France, and the United Nations. Modern legal systems have embraced these principles, have "widely interpreted the intuitive connection between inequality and injustice", and seen equality as a "cardinal virtue of political, social, and legal systems". ${ }^{31}$ If the House of Lords purports to uphold justice, it must assert greater equality and legal protections for the diverse, and the vulnerable, members of society, particularly in light of the imminent incorporation of the Human Rights Act 1998.

\section{Conclusion}

The House of Lords based its decision regarding Mr L's legal status in a best interest argument, while admitting the influence of financial considerations. In light of progressive developments in our notions of justice, we must creatively employ all feasible legal and ethical strategies to assure the greatest protection for our least vocal citizens.

\section{Acknowledgement}

The author wishes gratefully to acknowledge the comments of Yolanda Zaragoza, James Diesfeld, $\mathrm{MD}$, Joanne Conaghan and the anonymous assessors. The views expressed are the author's own.

Kate Diesfeld, $\mathcal{F D}$, is Lecturer and Legal Supervisor, Kent Law Clinic (Mental Health and Learning Disability) at Kent Law School, University of Kent, Canterbury, Kent. Please forward communications to kdiesfeld@hotmail.com

\section{References and notes}

1 Regina v Bournewood Community and Mental Health NHS. Trust, Ex parte L [1998] 3 WLR 107.
2 Regina v Bournewood Community and Mental Health NHS Trust, ex parte L [1998] 2 WLR 764

3 See reference 2: 770

4 Fennell P. Doctor knows best? Therapeutic detention under the common law, the Mental Health Act, and the European Convention. Medical Law Review 1998;6:322-53, 328.

5 Hodgson J. Detention, necessity, common law and the European convention: some further aspects of the Bournewood case. Fournal of Mental Health Law 1999;1:23-32, 23.

6 See reference 2: 764 .

7 See reference 1: 110-21.

8 See reference 1: 121 .

9 Schopp R. Therapeutic jurisprudence and conflicts among values in mental health law. In: Wexler D, Winick B, eds. Law in a therapeutic key. Durham, NC: Carolina Academic Press, 1996: 723-38, 733 .

10 See reference 1: 116

11 See reference 1: 112 .

12 Emerson E, McGill P, Mansell J, eds. Severe learning disabilities and challenging behaviours. London: Guilford Press, 1990: 7

13 Murphy G. Understanding challenging behaviours. In: Emerson E, McGill P, Mansell J, eds. Severe learning disabilities and challenging behaviours. London: Guilford Press, 1990: 37-68, 54.

14 See reference 13: 53

15 Durand VM. Severe behaviour problems: a functional communication training approach. London: Guilford Press, 1990: 19.

16 See reference 13: 50

17 See reference 9: 733 .

18 See reference 1: 119.

19 See reference 1: 114 .

20 See reference $1: 115$

21 See reference 1: 122

22 Gooding C. Blackstone's guide to the Disability Discrimination Act 1995. London: Blackstones, 1996: preface.

23 See reference 23: 34

24 See reference 23: 36.

25 Polyviou PG. The equal protection of the law. London: Duckworth, 1980: 1 .

26 See reference 26: 2 .

27 See reference $26: 3$.

28 R v Home Secretary ex parte Khawaja [1984] 1 AC 74, 111.

29 See reference 26: 9 .

30 See reference 26: 4

31 See reference 26: 7 .

32 For a comprehensive analysis of the application of the Human Rights Act 1998, see reference 4: 332-53. Also see article 14 of European Convention on Human Rights, which prohibits discrimination with regards to application of rights within the convention.

\section{News and notes \\ Ethics and genetics}

An Advanced Europen Bioethics Course, Ethics and Genetics, will be held from 16-18 November 2000 in Nijmegen, the Netherlands. Specialists from various countries will discuss, for example, ethics and the Human Genome Project; genetic counselling; genetic screening; human gene therapy, and geneticisation. All lectures and plenary sessions will be held in English. The course fee is Dfl 650. For further information please contact: $N$ Steinkamp, Catholic University Nijmegen, 232 Dept of Ethics, Philosophy and History of Medicine, PO Box 9101, 6500 HB Nijmegen, Netherlands. Telephone: 003124 3615320; fax: 003124 3540254; email: n.steinkamp@efg.kun.nl 